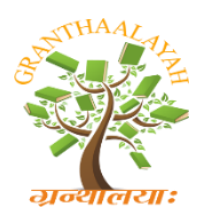

\author{
INTERNATIONAL JOURNAL OF RE
GRANTHAALAYAH \\ A knowledge Repository
}

Social

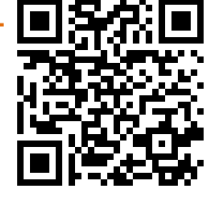

\title{
WAGE LEGAL SYSTEM BASED ON THE CONCEPT OF THE PANCASILA WELFARE STATE
}

\author{
Ahmad Hunaeni Zulkarnaen *1 \\ ${ }^{*}$ Postgraduate Law, Universitas Suryakancana, Indonesia
}

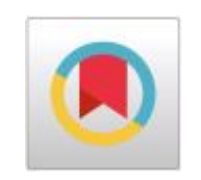

\begin{abstract}
Indonesia as a Welfare State based on Pancasila is tasked with carrying out people's prosperity, the state is allowed to interfere in the private lives of its citizens, one of which interferes in the Employment field including in the wage field, which has a variety of main problems including: Low wages for lower workers, lowest wage gap and highest, Variation in the wage component, Unclear relationship between wages and productivity, Workers' living needs, Social inequality, Work performance, and Human values and self-esteem. So, the purpose of this article is to analyze the legal system of remuneration based on theories and viewpoints of legal goals. The conclusion of this article is that the legal system of remuneration needs to be assessed based on theories of legal objectives such as ethical theory, utility theory and theorizing theory and based on legal objectives from the point of view, namely the point of view of positive-normative or dogmatic juridical law, where the objective of wage law is at emphasize the legal certainty, the point of view of legal philosophy, where the goal of wage law is emphasized in terms of justice, and the viewpoint of the sociology of law, where the purpose of wage law is emphasized on the benefit aspect. The results of the study are based on the theories and the objectives of the legal field, it is expected to be able to describe the wage legal system that can be in line with the ultimate goal of industrial relations, namely "the welfare of all parties (employers and workers)" or the wage legal system that fulfills a decent living for humanity that correlates with company productivity or profit.
\end{abstract}

Keywords: Country; Pancasila; Welfare; Wages Law.

Cite This Article: Ahmad Hunaeni Zulkarnaen. (2020). "WAGE LEGAL SYSTEM BASED ON THE CONCEPT OF THE PANCASILA WELFARE STATE." International Journal of Research - Granthaalayah, 8(3), 86-97. https://doi.org/10.29121/granthaalayah.v8.i3.2020.132.

\section{Introduction}

The concept of the state of Indonesia, is a democratic rule of law based on Pancasila, this can be seen in the formulation of paragraph 4 (four) of the Preamble of the 1945 Constitution which states that than that ... to the Almighty God, just and civilized humanity, the Indonesian Unity and Society which is led by wisdom in Consultation or Representation, and by realizing a social justice for all Indonesian people. 
In addition to adhering to the concept of a democratic rule of law based on Pancasila, Indonesia also adheres to the concept of a Prosperity State (Wohlfaart Staats). The state of Indonesia which protects all of the Indonesian people and all of Indonesia's blood and to promote public welfare ..... .. The type of Indonesian Prosperity State is "organizing people's prosperity based on Pancasila and the 1945 Constitution".

In the concept of the state of Indonesia as a Prosperity State, the state is the only tool for carrying out people's prosperity. Here the state is active in organizing the prosperity of its citizens for the benefit of all the people and the state, in the type of prosperity the duty of the state (Indonesia) is merely to carry out the people's prosperity as much as possible [1]. Because the state is active in organizing the prosperity of its citizens for the benefit of all the people and the state, for that the Indonesian state is allowed to interfere in the private lives of its citizens, one of which, is that the Indonesian state interferes in the field of Manpower including in the area of wages.

The existence of interference by the Indonesian state in the area of wages is motivated by wage problems that always arise which are triggered by conflicts of interest between employers and workers. The main problems of remuneration include a) Low wages for lower workers; b) The lowest and highest wage gap; c) Variation in the wage component; d) Unclear relationship between wages and productivity [2]. For this reason, in this scientific paper, the author tries to explain the correlation of the purpose of wage law which refers to several theories of the purpose of law, so that the outcomes of this scientific paper are the wage problems as described above, so that the wage legal system can be used as an instrument to realize the goal of Indonesia as a Prosperity State in an effort to realize prosperity or welfare for all Indonesian people, namely a wage legal system that meets a decent living for humanity which correlates with productivity or corporate profits.

\section{Results and Discussions}

\subsection{Indonesia Is A Welfare State Based on Pancasila}

If we trace the discussion in the sessions of the Indonesian Independence Preparatory Agency for Investigation (BPUPKI), we will find an opinion that wishes that an independent Indonesian state to be formed is a welfare state, a state that is sovereign of the people, a country that wants to realize justice, a state that guarantees health the people, a country that guarantees the freedom of the people to associate, gather and express opinions. This was explained by M. Yamin, Soekarno, Hatta and others [3].

M. Yamin, among others, said: “ that the state to be formed is only for the entire people, for the benefit of the entire nation which will stand strong within its own state [4]. He further added: The people's welfare which is the basis and purpose of an independent Indonesian state is to summarize community justice or social justice [5].

On the same occasion Sukarno said: "People who had felt themselves lacking in food, lacked clothes, created a new world in which there was justice, under the leadership of Ratu Adil, therefore if we really truly understood, remembered, loved the people: Indonesia, let us accept the 
principle of the rechtsvaardigheid sociale, that is not only political equality, even though on the economic field we must hold equality, meaning the best possible joint welfare [6] "

Furthermore, it is good to see that Sukiman's opinion which is more concerned with power is in the people rather than the formal form of the state, whether a republic or kingdom; he said: For me about the republic or kingdom, in this day and age, it is a matter of "etiquette" only, because in it the guaranteed or recognized power that is in the people is the sovereignty of the people, even in a state in the form of a kingdom; in modern times there is no longer a form of kingdom "despotisch" or "feudalisch" as before especially for our nation that already has a level of civilization that is not inferior to some other countries on earth [7].

If we pay attention to this, it can be concluded that the state desired by the Indonesian people is a country that guarantees the welfare of the people, which guarantees justice and human rights. Such a state cannot be otherwise a rule of law [8]. If the concept of continental European rule of law and the concept of the Anglo-Saxon rule of law are based on individualistic liberalism, then the concept of the rule of law of Indonesia is based on the Indonesian way of life, Pancasila [9].

The difference in this case mainly lies in the problem of the position of the individual against society and the rights and obligations of individuals towards the community, this difference is due to the influence of worldview and historical background of the Indonesian nation. Therefore, the concept of the rule of law in Indonesia is also different from the concept of a liberal rule of law. The concept of the Indonesian rule of law is a democratic rule of law based on Pancasila [10].

Indonesia formed its country by proclamation which is an embodiment of a one-goal agreement, the country desired by the Indonesian people, the answer was found in the Preamble to the 1945 Constitution paragraph 2 (two), namely: "............ the Indonesian state, which is independent, united, sovereign, just and prosperous [11]". And if the sentence is connected to the state's purpose contained in paragraph 4 which reads: "........... protect all the people of Indonesia and all of Indonesia's blood and to promote public welfare, educate the nation's life, and participate in carrying out world order, based on independence, eternal peace and social justice [12]”.

Then it can be concluded that the state that was intended to be formed (at that time) by the Indonesian nation was a "welfare state" This was revealed by Sukarno in the BPUPKI (Indonesian Investigation Preparatory Agency Preparatory Agency) session on June 1, 1945, as follows: " The people want prosperity, people who were previously lacking in food, clothing, creating a new world in which there is justice, under the leadership of Ratu Adil, therefore, if we really truly understand, remember, love the people of Indonesia, let us accept the principle of things rechtvaardigheid sociale (social justice), that is not only political equality, but also on the economic field, we must hold equality, meaning the best common welfare [13].

In Western literature the "welfare state" is called verzorggingsstaat or sociale rechtsstaat. Prosperity means material and spiritual prosperity, the choice of the Indonesian people directly to the welfare state, because of the bitter experience of the Indonesian people under the Dutch colonialism which not only lacked food and clothing. But it also lacks spiritual well-being, because the Indonesian people have almost no freedom. Political organizations are always closely 
monitored, even broadcasting religion (Islam) continues to be overshadowed by the Dutch secret service (PID) [14]

What is the nature of the state in the view of the Indonesian people? According to Padmo Wahjono, the state is "the life of a group of Indonesian people who, thanks to the grace of God Almighty, are driven by a noble desire for a free national life" this is the nature of the state according to the ideals of the Pancasila state [15]. Based on the explanation above, Indonesia adheres to the concept of a welfare state, which means that people's welfare is the basis and objective of an independent Indonesian state. In short, community justice or social justice, or Indonesia adheres to the concept of the State of Material Law (based on Pancasila), a material state law is a development of the state formal law, in the formal state of law the actions of the authorities must be based on the law or the principle of legality must apply, in the material state law in matters of urgency and in the interests of citizens, the authorities are justified to act in violation of the law (the principle of opportunity) [16].

The development of society and the needs of the community (Indonesia) are not enough if only formally regulated by the principle of legality, as a result the formal legal state has been criticized quite sharply in the Netherlands, so Scheltema considers that there are many policy actions from the government in various provisions. This is made possible by the delegation of legislative power to the government in making its implementing regulations, and the existence of freisermessen allows the government to guarantee fairer order in an effort to meet the needs of the community [17]. The purpose of delegation by forming this law, is because the task of state administrators is no longer just to maintain the existing order, but also to issue a fair order. For this reason, a wider scope of freedom of action by the government is needed, namely through increasing the provision of freisermessen to the government to organize a welfare state based on Pancasila [18].

In the concept of a prosperous state or wohlfaartstaats the state fully serves the community, the state is the only means for carrying out people's prosperity. Here the state is active in organizing the prosperity of its citizens for the benefit of all the people and the country. So in this type of prosperity the task of the state is merely to carry out the people's prosperity as much as possible [19]. Because the state is active in organizing the prosperity of its citizens for the benefit of all the people and the country, the Indonesian state is allowed to interfere in the private lives of its citizens, one of which, is that the Indonesian state interferes in the field of Manpower including in the wage field for example with the Government Regulation No. 08 of 1981 regarding Wage Protection, so specifically labor law or wage law originally based on the contents of the rule of law included in the category of Private (civil) Law Rule entered into the Public Law Rule, because in order to tackle certain employment problems government (state) intervention requires, among others : 1) In the form of: a) Licenses involving the field of employment; b) Determination of minimum wages (wage protection); c) Problems in resolving industrial relations disputes or termination of employment, and so on. 2) The existence of the application of sanctions against labor violations or criminal acts [20].

Budiono divides the nature of Labor Law into 2 (two), which are imperative and facultative. Law which is imperative or dwingwnrecht (law forcing), meaning that law must be obeyed absolutely, must not be violated. For example: 1) Article 42 paragraph (1) of Law Number 13 of 2003 concerning Manpower (UUK), concerning the need for permits to use foreign workers; 2) Article 
59 paragraph (1) of the Law on Manpower, regarding the provisions on making certain time work agreements (PKWT); 3) Article 153 paragraph (1) UUK, prohibition on terminating work relations (PHK) on certain cases; 4) Article 13 Regulation of the Minister of Manpower Number PER-01 / MEN / 1999, concerning prohibitions for employers who pay wages lower than the Minimum Wage [21].

While the law which is facultative or regelendrecht or aanvul-lenrecht (the law that regulates / complements), the law can be ruled out in its implementation. For example: 1) Article 51 paragraph (1) of the Manpower Act, regarding employment agreements can be written or unwritten; 2) Article 60 paragraph (1) of the Manpower Act, regarding work agreements for an indefinite period of time may require a trial period of 3 (three) months; 3) Article 16 Government Regulation No. 8 of 1981 concerning employers' freedom to pay salaries in the usual place [22].

\subsection{Government Interventions in The Wage Sector}

Wages are one of the most sensitive aspects of work relations and industrial relations. Between $70 \%-80 \%$ of cases that occur in employment relations and industrial relations contain wage problems and various related aspects, such as benefits, wage increases, wage structures, wage scales and so on [23]. For this reason, government intervention is needed, because the government is very interested in harmonizing wages that fulfill a decent life for humanity and achieving work productivity, by taking into account: a) The living needs of workers; b) Social inequality; c) Job performance; and d) Human values and dignity [24].

The government adopted a Minimum Wage Determination policy that was based on the Minimum Physical Needs (KFM) developing into the Minimum Living Needs (KHM), applied on a microregional basis with the intention of: a) as a safety net; b) As a means to improve the lives of the lowest groups; c) as a tool for income distribution; d) Wages above the minimum wage are regulated internally in the company [25].

As explained above, government policies in the area of wages are motivated by wage problems that always arise which are triggered by conflicts of interest between employers and workers. The main problems of remuneration include a) Low wages for lower workers; b) The lowest and highest wage gap; c) Variation in the wage component; d) Unclear relationship between wages and productivity [26].

\subsection{The Purpose of Legal Wages and Legal Theories}

The definition of wages according to Government Regulation No. 08 of 1981 concerning Wage Protection, is: "An acceptance in return from employers to workers for a job or service that has been or will be done, expressed or valued in the form of money that has been determined according to an agreement or legislation, regulations, and are paid on the basis of a work agreement between the employer and the worker, including benefits for both the laborers themselves and their families".

According to Article 1 point 30 of Law Number 13 Year 2003 concerning Manpower (UUK), wages are: "Workers' rights are received and expressed in money as compensation from employers 
or employers to workers who are determined and paid according to an agreements, agreements or laws and regulations, including benefits for workers and their families for work or services that have been or will be performed".

Based on Article of the 1945 Constitution it is stated that wages must fulfill a decent living for humanity. Thus, the fulfillment of a decent wage for livelihoods and humanity is a concept of remuneration that is constitutionally applicable in Indonesia. Therefore, manpower law defines wages as basic rights of workers that must be fulfilled by employers. If employers do not pay workers' wages, this is a violation of human rights, and is a crime that can be convicted. The concept of wages in Indonesia today is shifting from civil rights to violations of human rights that are criminal in nature [27].

According to Suwarto [28], with the above definition of wages, on one hand wages are workers 'rights and employers' obligations, on the other hand workers are obliged to give time, energy and thoughts to work or provide services. In addition, we also hold that wages also have a social nature, where the amount of wages and benefits must be able to meet the needs of families or wages must meet a decent living for humanity, namely meeting the needs of home, board, food, education, health, recreation and others -other. So that the wage legal system can overcome wage problems that always arise that are triggered by conflicts of interest between employers and workers as described above.

The purpose of wage law can refer to the purpose of law, many theories about the purpose of law, including the purpose of wage law.

\section{1) Ethical Theory}

Ethical theory holds that the purpose of law (wage law: the author) is to bring about justice, according to Aristotle, justice means giving everyone what is part of or their rights (ius suum cuique tribuere). Part of the rights of each person is not the same, Aristotle distinguishes the existence of 2 (two) types, namely: a) Distributive justice, is justice that gives each person (worker) a part or ration (his salary) in accordance with his services, which is the principle of distributive justice rather than equality of parts, but comparability, meaning that by not ignoring the principle of remuneration must fulfill a decent living for humanity, workers with higher work productivity must be given higher wages than workers with lower productivity. Workers who have longer service periods, naturally receive higher wages than workers whose tenure has not been long, workers whose positions are higher or have greater responsibilities, receive higher wages than workers with lower positions and responsibilities smaller answer; b) Commutative justice, justice that gives to every person (worker) the same amount without regard to his services, which becomes the principle of commutative justice is the principle of equality [29]. For example, every worker has the right to get a minimum wage of a City or Regency Minimum Wage (UMK).

\section{2) Utility Theory}

Law (wage law) aims to realize what is useful or useful (doelmatig) for people (employers and workers), which is to realize happiness as much as possible for as many people (entrepreneurs and workers). Only in order does everyone (employers and workers) get the chance to realize happiness as much as possible [30]. Based on the theory of utility, the objective of wage law must be to make as much useful or useful happiness as possible for all parties involved in industrial relations 
(employers and workers), for wage law employers who are useful and useful, which can increase worker productivity in efforts to increase productivity or profit of the company, for wage law workers who are useful and useful is a wage law that can improve the welfare of workers and their families. This is in accordance with the ultimate goal of industrial relations arrangements (wage arrangements) conveyed by Suwarto, is to improve the welfare of all parties (employers and workers). Achieving this requires an increase in productivity (company profits) from time to time that correlates with the welfare of workers and their families [31].

\section{3) Theory of Protection}

Law (wage law) aims to provide protection or protect people (employers and workers), means to protect people (employers and workers) in the passive and active sense [32]:

- Protecting humans (employers and workers) in the passive sense, ie preventing arbitrary acts and violations of rights. Wage law to protect workers from arbitrary acts and violations of rights by employers, for example the amount of wages given by employers does not violate Government Regulation No. 08 of 1981 concerning Wage Protection. For workers, wages are a source of income that can be used to make ends meet. Therefore, in accordance with the objectives of someone working, then through increasing one's welfare wages can be increased. Because if wages get bigger, the greater the chance for someone to be able to meet and improve their standard of living, such as meeting the needs for clothing, food, shelter, health, recreation and others. For employers, the salary is not only as a production cost but also as an instrument to increase productivity, work ethic, work discipline of workers in an effort to increase productivity and company profits from time to time. There are several factors that affect the provision of wages at the company level, namely: a) Education and training; b) Labor market conditions; c) Proportion of wage costs with other costs; d) The use of technology; e) Company capability; f) The ability of workers' organizations; g) Government policies and interventions [33].

- Protect humans in the active sense, that is:

1) Includes all efforts to create social conditions that open the widest possible way and encourage humans to continuously humanize themselves, the purpose of the law is to create humane social conditions that enable social processes to take place naturally, so that every human being has a fair opportunity broad to develop the potential (talents and abilities) of humanity as a whole [34]. Based on the explanation above, the objective of wage law is to cover all efforts to create conditions of industrial relations that open the widest possible way and encourage all parties (employers and workers) to continuously humanize themselves, the purpose of wage law is to create conditions of industrial relations that humane that allows the processes of industrial relations to take place naturally, so that every party in industrial relations (employers and workers) fairly has the broad opportunity to develop their full potential (talents and abilities) for humanity, that is, a continual increase in productivity or profits companies that correlate with the welfare of workers or laborers and their families.

2) Maintaining and developing humane morality and the noble moral ideals of the people based on God (see explanation of the 1945 Constitution), the wage legal system can increase worker productivity which correlates with company productivity or profit, because the wage legal system can maintain and develop mind humanitarian character and 
noble moral ideals of the people based on God, namely the wage legal system that can meet the needs of workers and their families, including meeting the needs of clothing, shelter, food, health, education, saving, recreation and others, while still can increase company productivity or profit from time to time [35].

3) Efforts to realize shelter, are businesses: a) Order and order (in an industrial relationship); b) True peace, peaceful peace (industrial peace); c) Justice (wage justice) includes, distributive justice, commutative, protective justice (social justice theory); d) Welfare and social justice (for all parties involved in industrial relations, for wage workers to improve the welfare of workers or laborers and their families, wage employers can motivate workers or laborers to improve work productivity, work ethics and work discipline) ; e) Maintenance and development of morals (noble character and ideals) based on the Almighty God for all parties involved in an industrial relationship [36].

True peace (in industrial relations) will be realized if the members of the community (all parties involved in an industrial relationship) can feel inner peace, peace there will be if the community members (all parties involved in an industrial relationship) feel confident: 1) The survival of the exercise of rights does not depend on mere physical or non-physical strength (but depends on the productivity or profit of the company which correlates with the productivity or welfare of workers; 2) As long as they do not feel violating the rights or harming others, without worrying the community members (all parties involved in an industrial relationship): a) can freely carry out what he believes to be true (for example, workers carry out work in accordance with competencies and job descriptions or procedures set by the company); b) can freely develop their talents and pleasures (for example workers can increase their competence and the company can increase profits); c) feels that he will always receive fair, humane, fair and civilized treatment, even when he has made a mistake, that is, the worker or laborer is considered a subject of production or an employer partner, a partner in the production process, a partner in the company's profits, even a partner in the case of the company loss. Partners in profits, namely workers get a humane wage, wages that can meet the needs of workers and families, namely the needs of home, board, food, education, health, recreation and others [37].

\subsection{The Purpose of Legal Wages from Various Perspectives}

From the perspective of positive-normative or dogmatic juridical jurisprudence, where the purpose of law is emphasized on legal certainty. From the perspective of legal philosophy, where the purpose of law is emphasized in terms of justice. Enforce the same that should be treated the same (MSE). Not applying the same for something that should not be the same (old employees should have received a higher wage than new employees or fair contribution) [38].

The purpose of wage law according to various points of view, namely certainty and fairness is in line with the ultimate goal of industrial relations arrangements delivered by Suwarto, namely improving welfare for all parties (employers or workers), to achieve this it is necessary to increase productivity from time-to-time. Productivity can be achieved if there is work and business peace (Industrial peace) within the company, understanding of work and business peace (Industrial peace), including "rights and obligations (employers, workers) guaranteed and implemented [39]" which is a condition of working conditions (especially in the area of wages), which are divided 
into 2 (two) outlines, namely wage arrangements called labor legislation and terms of employment [40].

Wages are work norms (labor legislation), are workers' wage arrangements contained in legislation. According to Suwarto [41] this work norm, is imperative which must be implemented because it is mandatory, so it is binding on all companies, so that it is minimal macro. Macro in the sense of binding all companies without exception both the place, size, type of business, the nature of the legal entity, etc., and minimal in the sense that in practice the matters regulated can be carried out better or larger depending on the ability and will of the company as a individual. this is in accordance with the purpose of wage law based on the perspective of positive-normative or juridical dogmatic jurisprudence, where wage legal objectives are emphasized on legal certainty, for example employers are prohibited from paying wages to their workers or laborers lower than the minimum city or regency minimum wage (Vide Article 90 paragraph (1) Manpower Law).

Wages that are in terms of employment (terms of employment), are wage arrangements that have not been regulated or not regulated by statutory regulations. According to Suwarto [42] the arrangement (wage) is conditional micro. Micro in the sense is regulated only for certain companies individually. Conditional in the sense of arrangement (wage: author) adjusted to the condition or ability of the company concerned, the form of remuneration is a work requirement, can be set forth in a Work Agreement (PK), Company Regulations (PP) and Collective Labor Agreement (PKB). Examples of wages that are micro conditional, namely each company has its own wage system, both in determining the size of the basic wage, the distance between the highest wage with the lowest wage and the level of wages according to skills or achievements and years of service. In addition to wages, companies usually provide benefits. Allowances are provided for various purposes and purposes, both as an appreciation for the responsibilities incurred (position allowance) as an incentive to increase discipline (attendance benefits), in addition to adjusting price differences for those who work in certain places (expensiveness benefits) and others [43].

In determining the size of the basic wage, the distance between the highest wage with the lowest wage and the level of wages according to skills or achievements and years of service or in providing benefits according to the conditions or abilities of each company concerned, meaning that each company will be different or it is not the same in determining the size of the basic wage, the distance between the highest wage and the lowest wage and in determining wage levels according to skills or achievements and years of service or in providing benefits to the workers or laborers.

From the standpoint of legal sociology, where the purpose of law (wages) is emphasized in terms of benefits [44], namely the benefits of wages for workers or laborers, employers and the government. Wage benefits for workers or laborers are a source of income that can be used to meet their daily needs. Therefore, in accordance with one's goals of work, then through increasing one's welfare wages can be increased, the greater the wages, the greater the chance for someone to be able to meet and improve their standard of living, such as meeting the needs for clothing, food, shelter, health, recreation etc. [45]. For workers or laborers is a source of income to meet the needs of themselves and their families. Therefore, the level of wages must be able to meet their minimum needs. Psychologically wages can also create satisfaction for workers or laborers. Institutional 
work performance for workers or laborers is also reflected among other things in the wage level. In addition, the macro level of wages also affects the overall purchasing power of the community [46].

For employers, wages are the cost of production. Therefore, every time an increase in wages means an increase in costs. But in human resource management wages must be seen as investment or human investment, i.e. increases in wages or labor welfare can be seen as improvements or improvements in the quality of human resources or workers, the results of which will be obtained later. If wages and welfare are better, it is possible to improve health and nutrition, improve skills through additional education, training, reading, discipline improvement, improvement of work conditions, increased morale, work calm and others. These factors will encourage an increase in work productivity [47], which leads to an increase in productivity or profits of the company. Therefore, wages should be associated with work productivity, which basically the level of productivity must be higher than the level of wages. As such, wages are one way to motivate workers to increase productivity and work ethic [48].

\section{Conclusions}

Indonesia adheres to the concept of a welfare state, meaning that people's welfare is the basis and goal of an independent Indonesian state in an effort to realize community justice or social justice, the state as the only tool to realize active state social justice in carrying out social justice for all Indonesian people, therefore the state allowed to interfere in the private lives of its citizens including in the field of employment, one of which is in the wage field, considering that wages also have a social nature, where the amount of wages and benefits must be able to meet the needs of workers and families, wages must meet a decent living for humanity, that is, meeting needs for clothing, housing, food, education, health, recreation and others. With the social legal system of remuneration, the legal system of remuneration is expected to be able to overcome the problem of remuneration that always arises which is triggered by a conflict of interest between employers and workers, the cause of a conflict of interest due to: a) Low wages for lower workers; b) The lowest and highest wage gap; c) Variation in the wage component; d) Unclear relationship between wages and productivity. Efforts to overcome conflicts of interest as described above, the formation of a wage legal system needs to be assessed based on theories and points of view of legal objectives. From theories of legal purposes such as: ethical theory, utility theory and guardian theory. Establishment of remuneration system based on legal objectives from the point of view, such as: From the perspective of positive-normative or dogmatic juridical law, where the goal of remuneration is emphasized on legal certainty, the perspective of legal philosophy, where the objective of remuneration law is emphasized in terms of justice, and the viewpoint of legal sociology, where the purpose of wage law is emphasized on the benefit side.

\section{References}

[1] Ni'matul Huda, Negara Hukum, Demokrasi Judicial Review, UII Press Yogyakarta, Yogyakarta, 2005.

[2] Aloysius Uwiyono,. Dkk, Asas-Asas Hukum Perburuhan, PT RajaGrafindo Persada, Cetakan ke 3 (tiga), Depok, 2018.

[3] Azary, Negara Hukum Indonesia, Analisis Yuridis Normatif Tentang Unsur-Unsurnya, UI Press, Jakarta, 1995. 
[4] M. Yamin dalam Azary, Negara Hukum Indonesia, Analisis Yuridis Normatif Tentang Unsur Unsurnya, UI Press, Jakarta, 1995.

[5] M. Yamin dalam Azary, Negara Hukum Indonesia, Analisis Yuridis Normatif Tentang Unsur Unsurnya, UI Press, Jakarta, 1995.

[6] M. Yamin dalam Azary, Negara Hukum Indonesia, Analisis Yuridis Normatif Tentang Unsur Unsurnya, UI Press, Jakarta, 1995.

[7] Azary, Negara Hukum Indonesia, Analisis Yuridis Normatif Tentang Unsur-Unsurnya, UI Press, Jakarta, 1995.

[8] Azary, Negara Hukum Indonesia, Analisis Yuridis Normatif Tentang Unsur-Unsurnya, UI Press, Jakarta, 1995.

[9] Azary, Negara Hukum Indonesia, Analisis Yuridis Normatif Tentang Unsur-Unsurnya, UI Press, Jakarta, 1995.

[10] Azary, Negara Hukum Indonesia, Analisis Yuridis Normatif Tentang Unsur-Unsurnya, UI Press, Jakarta, 1995.

[11] Azary, Negara Hukum Indonesia, Analisis Yuridis Normatif Tentang Unsur-Unsurnya, UI Press, Jakarta, 1995.

[12] Azary, Negara Hukum Indonesia, Analisis Yuridis Normatif Tentang Unsur-Unsurnya, UI Press, Jakarta, 1995.

[13] Azary, Negara Hukum Indonesia, Analisis Yuridis Normatif Tentang Unsur-Unsurnya, UI Press, Jakarta, 1995.

[14] Azary, Negara Hukum Indonesia, Analisis Yuridis Normatif Tentang Unsur-Unsurnya, UI Press, Jakarta, 1995.

[15] Azary, Negara Hukum Indonesia, Analisis Yuridis Normatif Tentang Unsur-Unsurnya, UI Press, Jakarta, 1995.

[16] Abu Daud Busroh, Ilmu Negara, Cetakan Pertama, Bumi Aksara, Jakarta, 1990.

[17] Azary, Negara Hukum Indonesia, Analisis Yuridis Normatif Tentang Unsur-Unsurnya, UI Press, Jakarta, 1995.

[18] Ni'matul Huda, Negara Hukum, Demokrasi Judicial Review, UII Press Yogyakarta, Yogyakarta, 2005

[19] Padmo Wahjono, Ilmu Negara Suatu Sistematik dan Penjelasan 14 Teori Ilmu Negara dari Jellinek, Melati Study Group, Jakarta, 1977.

[20] Abdul Khakim, Pengantar Hukum Ketenagakerjaan, Berdasarkan Undang-Undang Nomor 13 Tahun 2003, PT Citra Aditya Bakti, Bandung, 2003.

[21] Abdul Rachmad Budiono, Hukum Perburuhan di Indonesia, Cet I, PT Raja Grafindo Persada, Jakarta, 1995.

[22] Abdul Rachmad Budiono, Hukum Perburuhan di Indonesia, Cet I, PT Raja Grafindo Persada, Jakarta, 1995.

[23] Suwarto, Hubungan Industrial Dalam Praktek, Asosiasi Hubungan Industrial Indonesia, Jakarta, 2003.

[24] Aloysius Uwiyono,. Dkk, Asas-Asas Hukum Perburuhan, PT RajaGrafindo Persada, Cetakan ke 3 (tiga), Depok, 2018.

[25] Aloysius Uwiyono,. Dkk, Asas-Asas Hukum Perburuhan, PT RajaGrafindo Persada, Cetakan ke 3 (tiga), Depok, 2018.

[26] Aloysius Uwiyono,. Dkk, Asas-Asas Hukum Perburuhan, PT RajaGrafindo Persada, Cetakan ke 3 (tiga), Depok, 2018.

[27] Aloysius Uwiyono,. Dkk, Asas-Asas Hukum Perburuhan, PT RajaGrafindo Persada, Cetakan ke 3 (tiga), Depok, 2018.

[28] Suwarto, Hubungan Industrial Dalam Praktek, Asosiasi Hubungan Industrial Indonesia, Jakarta, 2003. 
[29] Tim Pengajar FH Unpar, Pengantar Ilmu Hukum, Universitas Katolik Parahyangan, Bandung, 1995.

[30] Tim Pengajar FH Unpar, Pengantar Ilmu Hukum, Universitas Katolik Parahyangan, Bandung, 1995.

[31] Suwarto, Hubungan Industrial Dalam Praktek, Asosiasi Hubungan Industrial Indonesia, 2003.

[32] Tim Pengajar FH Unpar, Pengantar Ilmu Hukum, Universitas Katolik Parahyangan, Bandung, 1995.

[33] Widodo Suryandono dalam Aloysius Uwiyono., Dkk, Asas-Asas Hukum Perburuhan, Edisi Kedua, PT RajaGrafindo Persada, Depok, 2018.

[34] Tim Pengajar FH Unpar, Pengantar Ilmu Hukum, Universitas Katolik Parahyangan, Bandung, 1995.

[35] Tim Pengajar FH Unpar, Pengantar Ilmu Hukum, Universitas Katolik Parahyangan, Bandung, 1995.

[36] Tim Pengajar FH Unpar, Pengantar Ilmu Hukum, Universitas Katolik Parahyangan, Bandung, 1995.

[37] Tim Pengajar FH Unpar, Pengantar Ilmu Hukum, Universitas Katolik Parahyangan, Bandung, 1995.

[38] Hyronimus Rhiti, Filsafat Hukum, edisi lengkap, (dari klasik sampai postmodernisme), Universitas Atma Jaya, Yogyakarta, Yogyakarta, 2011.

[39] Suwarto, Hubungan Industrial Dalam Praktek, Asosiasi Hubungan Industrial Indonesia, Jakarta, 2003.

[40] Suwarto, Hubungan Industrial Dalam Praktek, Asosiasi Hubungan Industrial Indonesia, Jakarta, 2003.

[41] Suwarto, Hubungan Industrial Dalam Praktek, Asosiasi Hubungan Industrial Indonesia, Jakarta, 2003.

[42] Suwarto, Hubungan Industrial Dalam Praktek, Asosiasi Hubungan Industrial Indonesia, Jakarta, 2003.

[43] Suwarto, Hubungan Industrial Dalam Praktek, Asosiasi Hubungan Industrial Indonesia, Jakarta, 2003.

[44] Hyronimus Rhiti, Filsafat Hukum, edisi lengkap, (dari klasik sampai postmodernisme), Universitas Atma Jaya, Yogyakarta, Yogyakarta, 2011.

[45] Suwarto, Hubungan Industrial Dalam Praktek, Asosiasi Hubungan Industrial Indonesia, Jakarta, 2003.

[46] Suwarto, Hubungan Industrial Dalam Praktek, Asosiasi Hubungan Industrial Indonesia, Jakarta, 2003.

[47] Suwarto, Hubungan Industrial Dalam Praktek, Asosiasi Hubungan Industrial Indonesia, Jakarta, 2003.

[48] Widodo Suryandono dalam Aloysius Uwiyono., Dkk, Asas-Asas Hukum Perburuhan, Edisi Kedua, PT RajaGrafindo Persada, Depok, 2018.

*Corresponding author.

E-mail address: ahmadhunaeniz@unsur.ac.id 